\title{
MORE LAW - LESS ORDERLINESS
}

\author{
Andrew Durand
}

\begin{abstract}
"A sovereignty over sovereigns, a government over governments, a legislation over communities, as contradistinguished from individuals, as it is a solecism in theory, so in practice is it subversive of the order and ends of civil polity." James Madison and Alexander Hamilton ${ }^{1}$
\end{abstract}

To persuade the electors of New York to ratify the new Constitution of the United States giving Congress power to legislate directly over citizens of the United States rather than the alternative of giving Congress the power to coerce States to pass federal legislation, Madison advanced this dreadful theory. Whether a sovereignty over sovereigns is an appropriate description of the European Union, and, whether it has been subversive of the order and ends of civil polity, will be explored.

Although it was certainly designed as a step on the path towards some still undefined political union which would be capable of managing a foreign policy, the European Community Treaties were not constructed as a Constitution, let alone as a federal constitution, but rather as a number of sophisticated procedures to enable sovereign states to work together, in some defined cases, as a League of States and, in still narrower circumstances, produce joint decisions. The development of some form of largely unwritten Constitution on the basis of the original treaty structure, together with the Maastricht changes, in part by the European Court ${ }^{2}$ and in part by conventional acquiescence of a majority of the

* Professor of European Law, the University of Buckingham. This is a revised version of an inaugural lecture delivered at the University of Buckingham in April, 1996.

${ }^{1}$ Alexander Hamilton, The Federalist No.20, (2nd.ed.,Blackwell) at 97.

${ }^{2}$ The case of Van Gend en Loos v. Nederlandse Belastingsadministratie (Case 26/62) [1963] E.C.R. 1 contains the Court of Justice of the European Communities' fundamental assertion that the E.E.C. Treaty, as it then was, set up a New Legal Order in national law. That assertion is and remains entirely a priori. 


\section{THE DENNING LAW JOURNAL}

Member States, has been frustrated by Britains's alleged intransigence in refusing to accept this unwritten constitution as opposed to the rules of the written Treaty. The United Kingdom Government's White Paper, produced for the Maastricht II Intergovernmental Conference, A Partnership of Nations, presents the conclusion that the United Kingdom could continue this stance or, at least, contain the development of this constitution indefinitely. This conclusion seems to me to be mistaken.

Both the development of the unwritten constitution and Britain's intransigence have gone about as far as they can and somewhat beyond with regard to the underlying legislative policy of the European Community. Whether or not it becomes easier to pass legislation under the present legal system, as it probably will, paradoxically, what will continue to emerge is an entity with an ethic that more closely belongs in a unitary state than in a federal state or, if in a federal state, in one conceived on the highly unitary model of Germany, rather than on that of the United States, with, at least, its rhetoric of state rights. The current expression to describe the sort of edifice that is emerging is "cooperative federalism" 3 but that expression masks the reality of the coercion behind the notion of Community Loyalty or Bundestreue, the original concept in the German model. It is given surprisingly sharp teeth by the Court. ${ }^{4}$

Finally I suggest that the only way to influence a Union, where the sole or main criteria for the location of legislative competence, efficiency, has become deeply entrenched in the legal thought process, is to open up a real debate on an openly federal solution contained in a document, which is accepted and publicly acknowledged by all to be a memorandum of the Constitution of the European Union. $^{5}$

3 In U.S. politics this expression refers to the technique of making federal funds available to a State only on condition that the State comply with certain Federal policies as opposed to the naked force of the European Union model.

${ }^{4}$ Although art.5 E.(E.)C. Treaty, on which Community loyalty is based, could not itself give rise to rights, that article has been developed as the general launch pad for new remedies in the State court for breach of European Community, most recently Francovich liability: Francovich and Bonifaci v. Italian State (Joined Cases C-6 \& 9/90)[1991] E.C.R. I-5357. See the notion of Bundestreue which may well be a better analogy, the operation of which is explained in Herdegen, "After the TV judgment of the German Constitutional Court" (1995) 32 C.M.L.Rev. 1369 at 1374 .

5 There have been various unofficial attempts to draw up an acknowledged Constitution. The European Parliament went through the unusual process of asking a number of academics to draw up a Constitution for a European Union which was an exercise in political fantasy. The 


\section{MORE LAW - LESS ORDERLINESS}

\section{The concept that the Treaty contained overriding rights of free movement}

which could be vindicated by subjects, against even their own states, was one that has led to significant benefits and should be accepted by all who believe in the merits of a truly common market. ${ }^{6}$ Nothing in this article is designed to question, in any way, the significant contribution that the Court of Justice of the European Communities has made in ensuring that we have such a single market in Europe. ${ }^{7}$ The United Kingdom also claims to have played a rather important part in that development. ${ }^{8}$ The progressive extension of powerful and still dubious techniques, developed in the infancy of the Union, to ensure compliance with the basic rules of the Union, to ordinary directives, excites worry. That way lies a centralist Union.

Maastricht Treaty was clearly a Treaty on European Union rather than a Treaty of European Union even though it purports to constitute a European Union. That it was still using "Union" in the sense used in the Western European Union or in the phrase an ever closer union, as an aspiration or sense of direction rather than as a document that really acknowledged the Constitution of a European Union, is clear from the fact that it left the European Community Treaty structure intact. Only the European Community had legal personality.

6 The rule requiring States to refrain from unreasonably interfering with interstate commerce, the negative commerce clause, was found by the U.S. Supreme Court to be implicit in the grant of power to the United States Congress to regulate commerce. In the European Union it is the opposite way round. The negative commerce clause is express. The power to legislate is rather more circumscribed. The concept of a common market and the concept of an internal market have occasionally been juxtapositioned in an effort to show that the internal or single market involved even greater harmonization than the original concept of a common market. It required a degree of internal regulation which would once have been thought of as involving a common policy. See in particular the Titanium Dioxide (TiO2) case, Commission v. Council (Case C-300/89) [1991] E.C.R. I-2867 where the Court emphasized, in effect, that disparities in conditions of competition caused by legislation justified under art.100A rather than leaving it to the market to resolve. Although the TiO2 decision is still good law, it has hardly ever been followed.

${ }^{7}$ The decision of the European Court in Brasserie du Pecheur S.A. v. Germany and R.v.Secretary of State for Transport, ex parte Factortame (No.4) (Joined Cases C-46 \& 48/93) [1996] E.C.R. I-1029 and R. v. M.A.F.F., ex parte Hedley Lomas (Ireland) Ltd. (Case C-5/94) [1996] E.C.R. I-2553 would most clearly be justified if they were based on the fundamental principle of free movement. There would then be a concept of fundamental constitutional rights which a State interfered with at its peril. Unfortunately this was not the ratio of those cases.

${ }^{8}$ As the government points out in its White Paper (A Partnership of Nations, Cm.3169) claiming, at least in part, credit for the achievement of the then Commissioner, Lord Cockfield. 


\section{THE DENNING LAW JOURNAL}

Although a directive always gave instructions to the Member States, it was not designed to give instructions directly to the courts of the Member States or to their local governments and industries. The transformation of the directive, ${ }^{9}$ from its original concept as an international decision, like the decisions of the North East Atlantic Fishing Convention, into not merely a law-making instrument like federal legislation, but into an instrument in which, even trivial obligations imposed on states, are guaranteed in the same way as the Bill of Rights in the U.S. Constitution or the fundamental rights of the German Constitution, poses serious problems both conceptually ${ }^{10}$ and in practice. This fundamental constitutional change is inconsistent with the instrument, described in the Treaty as binding on the Member States to which it was addressed, as to the result to be achieved and involves, once more, the added theoretical difficulty of recognizing a power in the European Court to rule on the effects of the directive within each State. ${ }^{11}$

The change in the nature of the directive has come about, in part, because of the problems with slower or recalcitrant states. ${ }^{12}$ The Treaty provided ample means to shame such states into compliance by being brought back to the European Court to answer for their failure. Unfortunately the increasing and

${ }^{9}$ In French the term indicated administrative instruction from a hierarchical superior (perhaps the administrative circular): see for example Rene David Major Legal Systems of the World Today (3rd.ed., Sweet \& Maxwell, 1985) at 360.

${ }^{10}$ The directive was designed as a legislative instrument which would interfere least with State legislative procedure by leaving the power to formulate and lay down the rules to the Member State. It was not therefore directly applicable. An instrument that is not directly applicable but only indirectly through the instrument which is passed under State law should not be capable of directly giving enforceable rights to subjects.

${ }^{11}$ The court was given the power to interpret the Treaties and European Community Legislation. It was given no power to rule on the effects, in a member state, of breach of the European Community Treaty by a Member State. The European Court, in its famous Van Gend en Loos decision supra.n. 2 got round this by holding that it was simply interpreting the Treaty as impliedly requiring effects to be produced. It still left it to the State authority to fathom out what these effects actually were. The European Court had to resort to its familiar double negative argument which relies on stating that art. 189 does not say that it does not produce effects; a very strange argument indeed.

${ }^{12}$ Belgium and Italy, notoriously, had difficulty in complying with European Community directives by the date laid down, or even, in some cases, by a considerable date thereafter, because of their respective Constitutions which gave considerable autonomy to their regions. Italy took measures with the famous Pergola law to change its record of compliance. 


\section{MORE LAW - LESS ORDERLINESS}

entirely proper zeal of the Commission over the last decade may have given the appearance that matters were worse than they seemed. As one would imagine, in a union of States with very different constitutions, by far the largest problem with directives has concerned and, indeed, still concerns formal non compliance, i.e. failing to adopt the required legislation to give effect to the directives into national law by the date laid down but the problem is by no means as chronic as the cases might suggest. Of these failures, a distinction should be drawn between total non compliance which may be caused by legislative difficulties in getting the necessary legislation through the Bundesrat or the State parliaments or because of the general difficulties of the legislative process, and the far rarer case of contumacious non-compliance. Similarly partial non-compliance, getting it wrong, can be either intentional or negligent.

Given the wide powers of the government in England under the European Communities Act 1972, total non-compliance is infrequent, so that it is not surprising, that we are rarely in trouble on that ground. A few cases concern partial non-compliance where the State has purported to implement the directive, but has done so incorrectly, where, I suggest, at one time, an individual directive might have been more properly issued. At any rate that device, which was contemplated by the original treaty, has hardly, if ever, been used. ${ }^{13}$

When the United Kingdom is taken before the European Court, it often concerns a more fundamental disagreement between the United Kingdom and the Commission as to the meaning or scope of a directive. ${ }^{14}$ The failure to enforce a directive that the United Kingdom has duly implemented, substantial non-compliance, is largely unknown. Given the United Kingdom's system of independent enforcement officers and its conception of the rule of law, once a directive has been transformed and the transitional provisions have expired it is likely to be enforced. The deliberate failure to enforce a duly transformed directive does certainly happen. For example Germany did properly implement the First Company Law Directive but $90 \%$ of affected companies took no notice and did not file accounts. No action was taken against them. Similarly Spain implemented the Slaughterhouse directive but provided no sanctions for those who slaughtered in a manner prohibited by the directive. There is a widespread view that much of European Community law, although perhaps properly

${ }^{13}$ Many scholars have assured me that there are directives addressed to individual states but I have never actually found one nor seen one cited in a case.

${ }^{14}$ For example over the Environmental Impact Assessment Directive no. 85/337 O.J. 1985 (L175/446). 
transformed remains substantially unenforced. ${ }^{15}$ Again that can be controlled by better reporting processes and does not necessarily require the creation of private law remedies.

The Commission recently gave us a glimpse of its concept of the directive in its 12th.Report on Compliance with Community law by praising Luxembourg, commenting that:

Luxembourg makes a great effort to see that Community directives are properly transposed, regularly taking them over word for word so that divergences from Community law are rare. ${ }^{16}$

It further pointed out that in Luxembourg the Enforcement officers were the same as those who drafted the State regulations. Such a technique would not work in the common law world without an increased reliance on the Continental technique of binding administrative interpretations and administrative appeals since the rules in most directives are kept at such a level of generality and are often such an odd compromise that it would require either litigation or a change in the rule of law to give the directive any precision .

In the United Kingdom the concept that the administration can give precision to an instrument, after it has been laid before Parliament, even with the possibility of testing the issue in the administrative courts, is a solecism, although quite normal in many jurisdictions. We still expect the instrument to contain a complete set of instructions which lawyers can interpret with reasonable accuracy. Traditionally the English lawyer's training in drafting deeds and contracts was the same as statutory drafting. It fits in with the tendency to conceive of rules as detailed prescriptions, in contrast to the more Continental view of rules as being at a greater level of generalization in which the subject must try to follow the more general wishes of the ruler. A more comfortable relationship between enforcement officers and the Commission will lead on the one hand to a more uniform interpretation but on the other to a greater sense of centralization.

The European Court has, with remarkable success, ensured that most directives

${ }^{15}$ Although there is much anecdotal evidence in the newspapers there is surprisingly little actual evidence. The Commission's annual report to the European Parliament on compliance gives a few examples.

${ }^{16}$ See the Commission's 12 th. Report on Compliance, O.J.1995 (C.254) at 6 . This copy out method has been used in England. See in particular the regulations passed to give effect to Unfair Terms in Consumer Contracts Directive (S.I. 1994 No.3159). 
can effectively be enforced in the courts of the Member State, as a matter of State Constitutional law. Applying its basic principles, it has developed a number of techniques to ensure that, where possible, there is a State remedy to prevent breach of a directive.

In the early days, the Court indirectly gave effect to directives, by finding the objective sought by the directive to be already implicitly contained in the Treaty and capable of giving rights to subjects. The Court could give force to the directive in the guise of applying the Treaty: that is one explanation of the equal pay cases. The Court bypassed the issue of whether the equal pay directive could be regarded as law in the Member State, by reading the principle contained in the directive, back into the Treaty with the devastating effect that the obligation became backdated from 1976 to 1962 .

It is often said that there is a special difficulty for an English lawyer in learning how to deal with very broad principles, such as the principle that men and women should be paid equally. What is often not explained is that that principle is not actually to be found in the Treaty. It is, at best, a general principle implied in the Treaty. What the Treaty actually required was that each Member State, by a particular time, ensure the application of the principle that men and women should be paid the same. They were required to pass legislation. It should be contrasted with the terms of article 3 of the German Constitution which lays down that: "Men and women have a right to equality. No one shall be favoured or disadvantaged on grounds sex."

No one could doubt that each sovereign state had covenanted with the other sovereign states to ensure from a particular date the application of that principle. It was an enormous leap to hold that, even where a state had not carried out its duty, an aggrieved person could nevertheless treat its employer, as if the State had passed the relevant legislation to comply with its duty.

The reasoning that the Court applied to the interpretation of article 119 was later to be applied, with devastating effect, to directives issued by the community legislature. It held that a Court of a Member State could itself execute the obligation placed on a Member State: it could itself make good the failings of the legislature.

Its second technique was to hold that courts and tribunals were under a duty to interpret State law, so that it gave effect to the directive, as interpreted by the European Court. Although this might sound a relatively anodyne conclusion for an active court to reach, it was extremely radical when juxtaposed with the Court's original and creative method of interpretation of many of the directives. It postulated that the overriding aim of the Treaty or of legislation passed by the institutions was to achieve uniformity of application. Since this was its aim, the 


\section{THE DENNING LAW JOURNAL}

directive should be interpreted as having achieved its purpose.

Words in a directive were therefore to be given a special European meaning. The European Court could bring about quite radical changes in law by giving words a particular meaning: see for example the many cases in which the Court has given remarkable breadth to the word "pay" in article 119 of the Treaty and in the Equal Pay directive (the decision in Barber v. Guardian Royal Exchange ${ }^{17}$ which produced its radical result from a significant extension of the notion of pay, without any discussion of the alternative proposition). A consideration of the consequences of the interpretation adopted by the Court, is relevant in this context only to the issue of whether the Court should exercise its quite extraordinary power to suspend the operation of a provision for the past, which it has just declared has always been the law, a power normally belonging only to a legislative body.

Although the European Court had always emphasized that directives had to be interpreted in the light of their purpose, until the Court had deduced, from the preamble, what the overriding purpose of the instrument was, it might be very difficult for the relevant Department of State to get it right. ${ }^{18} \mathrm{Often}$ in the preamble of a directive there are remnants of earlier drafts and earlier purposes. The choice depends on the political concept of the kind of Community is intended. ${ }^{19}$

This is particularly evident in the case of the three social directives, the Transfer of Undertakings (Acquired Rights) Directive, the Collective Redundancy Directive and the Insolvency Directive where the concept of undertaking, business or part of a business came to mean, whatever concept would make the protection guaranteed by the directives as extensive as possible, without a nod to the economic problems that might ensue. ${ }^{20}$ In a state system such radical interpretation causes no insurmountable problems because the

\section{${ }^{17}$ (Case 262/88) [1990] E.C.R.I-1889}

${ }^{18}$ In the $T i O 2$ case, supran.6, where the Court concluded that the overriding purpose of the directive was to equalise conditions of competition. It further held that that purpose was by implication a legitimate purpose of art.100a. Finally it held that in the light of that purpose only art. $100 \mathrm{a}$ could be used as a legal base.

${ }^{19}$ The lawyer with inside knowledge may well be in a better position to advise a client than the lawyer confined to the text of the measure. The former will be able to keep track of the intentions of the Commision and relay that to his client.

${ }^{20}$ Directive 75/129, O.J. 1975 (L.48/29); Directive 77/187 O.J. 1977 (L.61/27); Directive 80/987 O.J. 1980 (L.283/23). 
legislation can always be changed by act of parliament or government regulation. In the Community without a proposal from the Commission it is in effect entrenched as part of the Constitution and in practice unalterable. ${ }^{21}$

Where no legislation was passed to give effect to the directive, either intentionally or negligently, or because English law was wrongly assumed already to comply with the directive, there was, according to the Court, still an obligation to make existing law comply with the terms of the later directive, in so far as it was possible to do so:

"..a national court hearing a case which falls within the scope of [the] Directive [....] is required to interpret its national law in the light of the wording and the purpose of that directive in order to [produce the result required by the directive], ${ }^{, 22}$

The court has moderated this obligation on a number of occasions and, in particular, in the case of State criminal legislation because of the danger of falling foul of the fundamental principle that no one should be punished except for a distinct breach of the law. Where a directive required the State to impose criminal sanctions on subjects and the Member State failed to change its laws, in any subsequent criminal prosecution for commission of a more general offence, such as selling food unfit for human consumption, the prosecutor could not rely on the terms of the directive to fix the content of the standard:Officier van Justitie v. Kolpinghuis Nijmegen B.V. ${ }^{23}$ and Pretore di Salo v. Persons Unknown. ${ }^{24}$

It would seem to follow that where a State has implemented the directive it would be wrong to go behind the detail of the state legislation to the text of the directive, to give precision to a criminal offence, except, possibly to acquit the accused. Given the Court's method of interpretation, where a statute was passed specifically to give effect to the directive, it might well hold that the distinct

${ }^{21}$ There is one example only of the Member States' unanimous amendment of the Treaty to lay down a preferred interpretation of the Treaty: see the Barber amendment "Protocol Concerning article 119 of the Treaty Establishing the European Community."

${ }^{22}$ Marleasing S.A.v.La Comercial Internacional de Alimentacion S.A. (Case C-106/89) [1990] E.C.R. I-4135.

${ }^{23}$ (Case 80/86) [1987] E.C.R. 3969; 1989 2 C.M.L.R. 18.

${ }^{24}$ (Case 14/86) [1987] E.C.R. 2545. 


\section{THE DENNING LAW JOURNAL}

breach of the law was defined in the directive together with the law passed to give effect to the directive.

This would arise typically with a standardization directives such as, for example the Electro Magnetic Compatibility Directive, ${ }^{25}$ Regulations for which became enforceable at the beginning of 1996. They may have laid down more generous transitional arrangements than the directive intended. Some of the enforcement authorities, which had dealt with the Commission directly, inevitably read the English regulations in the light of the Commission's intentions and interpretation. Fear, uncertainty and doubt will effectively mean a change in the relationship with the executive. English methods of interpretation will have to become more open-ended and less precise, or more dependent on insider knowledge.

In practical terms there cannot be two systems operating at the same time: one where a criminal penalty is being considered and one where the authorities seek an injunction. Nor can there really be one rule for regulations which lay down criminal sanctions and another for other regulations. If the United Kingdom increasingly adopts what are thought of as European methods of interpretation, particularly if the copy out technique is used, we will see a growth in the power of the executive and the discretion of the judiciary at the expense of the legislature. This particular interpretation principle is clearly very far reaching indeed, ${ }^{26}$ and goes far beyond the Pepper v. Hart ${ }^{27}$ type of principle. There is nothing theoretically difficult in the executive being bound by the explanation it gave to Parliament. It is clearly a wholly different doctrine where the terms of a directive cannot be relied on at all but instead recourse must be had to some very broad general principle the contours of which could only be known to the Court.

If the State failed to implement the directive, or wrongly implemented the directive, the European Court further held that an aggrieved person might be able to get a remedy to stop the State from applying inconsistent State law. At

${ }^{25}$ Directive 89/336 O.J. 1989 (L.139/19), as amended by the Terminal Equipment Directive, O.J. 1991 (L.128/1) and Directive 93/68 on the CE mark, O.J. 1993 (L.290/1), implemented by the Electromagnetic Compatibility (Amendment) Regulations 1994, S.I. 1994 No.3080.

${ }^{26}$ This principle is described as the doctrine of indirect effect to point up that it has nothing to do with ordinary techniques of interpretation.

${ }^{27}[1993]$ A.C. 593 . 


\section{MORE LAW - LESS ORDERLINESS}

one time this was called the estoppel effect of a directive. ${ }^{28}$

The extension of this principle to a so-called emanation of the State, such as a health authority or a nationalized industry, which could, just as if it were the Government, be stopped from doing anything which contravened, for example, the equal treatment directive ${ }^{29}$ even though neither a health authority nor a nationalized industry could have implemented the directive, shows the difficult conceptual problems. A Health Authority can be stopped from behaving inconsistently with the directive. It is not clear whether the doctrine goes further. It is still not altogether clear whether, based on the directive alone, an emanation of the State would have power in the absence of any statutory grant to behave consistently with the directive, as if the directive had been implemented, even if this meant depriving a citizen of a right previously enjoyed under State law. Yet this seems to be the implication of much of the modern case law.

The court has so far steadfastly refused to hold that a directive can ever give a right to one subject which it can enforce against another subject. That would have involved holding that a directive could directly impose obligations on a subject. Yet if a directive could give directions to a Health Authority or nationalized industry there is no theoretical reason why it should not direct everyone. Ownership is irrelevant. In my opinion it is right that there can be no allegation against a subject that it has broken the terms of a directive. It is the emanation of the State doctrine that is hard to justify. To the relief of many the European Court stuck to this distinction in Faccini Dori v. Recreb srl. ${ }^{30}$ In that case it signalled to the member states as well as to its own advocates general that it was not ready to extend the doctrine. Nevertheless even though a directive cannot directly impose an obligation on a subject it might still do so indirectly.

Where the State was under a positive duty to do something it looked, at first, as if there was nothing that an aggrieved subject could do, until some appropriate legislation was passed.Inevitably the principle of effectiveness led to granting a remedy even here. In Fratelli Costanzo SpA. v. Commune di Milano the plaintiff had tendered for the construction of a football stadium in Italy. ${ }^{31}$ His bid was disregarded, consistently with Italian law, on the grounds that it was unreasonably low. Unfortunately under the Public Procurement Procedures

${ }^{28}$ Publico Ministero v. Ratti (Case 148/78) [1979] E.C.R. 1629.

${ }^{29}$ Directive 76/207 O.J. 1976 (L.45/19).

${ }^{30}$ (Case C-91/92) [1994] E.C.R. I-3325.

${ }^{31}$ (Case 103/88) [1989] E.C.R. 1839. 
Directive, which was designed to prevent a State discriminating against foreign firms, there could be no simple rejection of a bid on that ground, without a proper procedure of enquiry. ${ }^{32}$ The Milan local authority was of course bound by Italian law. The issue arose as to whether it was bound to follow the proper procedure laid down by the directive. The Court held, against the advice of its advocate general, that the rejection of a bid, without following the proper procedure, was contrary to the directive. The advocate general considered that would mean that the directive directly obliged the Milan Town Authority to follow a particular procedure even though the directive had not been implemented.

The indirect obligation arose from the fact that the Court had failed to address the position of the contractor which had successfully tendered for the contract. The action in the State court was it seems to annul the decision to award the contract. The successful tenderer was thereby deprived of a right that it enjoyed under Italian law by virtue of an unimplemented directive. This is not very different from imposing an obligation directly on a subject.

Similar issues arose with the Environmental Impact Assessment Directive which had caused difficulties in most of the States. ${ }^{33}$ The Court held that planning permission which was granted, without holding an environmental impact assessment, was illegal. A local authority had to take what instructions it could, directly from the directive, rather than await national legislation, even though there could be no certainty how, under national legislation, the directive might have been implemented. This was the point made by Germany in the case that arose out of an extension to a power station in the local authority area of Hesse Darmstadt. ${ }^{34}$ Germany pointed to the huge range of discretion left to Member States which could integrate the Environmental Impact Assessment into the normal planning process or could lay down a special procedure. By virtue of the directive alone, and without waiting for the enactment of relevant legislation, it seems that the local government of Hesse Darmstadt, could and should have implemented the Environmental Impact Directive. Germany was in breach of the directive because the government of Hesse Darmstadt had not complied. This would mean, it seems, that a local government would have had the statutory authority to require the production of reports and documents from an applicant even though the directive had not been implemented and there was no statutory

${ }^{32}$ Directive 71/305 O.J. 1971 English Spec. Ed. 1971(II), 682.

${ }^{33}$ Environmental Impact Assessment Directive 1985 supra.n. 14.

${ }^{34}$ Commission v. Germany (Case C-431/92) [1995] E.C.R. I-2189 


\section{MORE LAW - LESS ORDERLINESS}

warrant under State law, or it could mean that the planning authority would have to decline to proceed until the directive was properly implemented. Either way it would be certain of litigation either for breach of the State rule of law or the European rule of law..

A further complication with such directives as the Environmental Impact Assessment Directive, is that they have to slot into complicated planning processes, involving the review of plans at various stages. Sometimes outline planning permission will already have been granted, in others some negotiations will already have taken place. The directive was properly vague about the transitional arrangements but the Court has held that, if a State was late in transposing a directive, it could not provide additional transitional rules, whereby projects already on course, did not need to comply with the directive. It held that projects initiated, after the date for compliance, had to be subject to the directive. This could mean, in effect, that the planning authorities would have to start enforcing the directive even before the national authorities had passed or were required to pass the necessary legislation unless the directive specifically permitted a further transitional period. "Form and Methods" in a directive like the Environmental Impact Assessment are central. The Court sees the extraction of minimum rights directly from the directive as part of the process of ensuring compliance, rather than as making sense of the process itself.

Judges and advocates general can be impressively candid about this process: M.Léger, one of the advocates general said in his Lomas opinion that his analysis of the cases demonstrated how "the principles of direct effect and indirect effects were simply expedients designed to ensure the enforcement of Community Law...." 35

The latest stage on the transformation process was the recognition, by the European Court, that formal non-compliance or partial non-compliance was a new Community wrong, giving rise to an action in damages in the municipal court, presumably in the nature of tortious or Aquillian liability against the State, and possibly an emanation of the State.

The most obvious difficulty, in principle, in creating a remedy in damages, was that the Court had also stated, as a general principle, that the Treaty was not intended to produce new rights of action or alter existing rights, except to hold that these were now to be available to enforce European law. ${ }^{36}$ Since there was

${ }^{35}$ Supra.n.7 at 2575 para.80, quoting from J.Steiner, "From direct effect to Francovich: shifting means of enforcement of Community Law" (1993) 18 E.L.R. 3 at 10.

${ }^{36}$ Rewe v. Hauptzollampt Kiel (Case 158/80) [1981] E.C.R. 1005 at 1838 para.44. 


\section{THE DENNING LAW JOURNAL}

no liability, in many of the Member States including the United Kingdom, for conduct by the Government, acting as a Government, for legislative activity, a remedy of damages was a true act of creation by the European Court.

This is what it did in the now famous case of Francovich v. Italy ${ }^{37}$ In that case Italy had been duly condemned, in a direct action, for failing to introduce legislation, to comply with the Insolvency Directive. Under this directive, every company was required to set up a redundancy fund. If the fund was not sufficient to pay the redundancy, then this was to be guaranteed by the State. The State was therefore to be paymaster of last resort. Since the legislation had not been passed and since Italian law provided nothing similar to the obligation under the directive, there was no opportunity for a claim by two employees against their employer, which had become insolvent. They, therefore, claimed damages against the Government. The Court held that the principle of effectiveness required there to be a remedy in damages.

The final irony of the case occurred, when Italy, later, transposed the directive into State law but nevertheless excluded the claim of persons in Francovich's position because of the type of company concerned. When the case came back to the European Court in Francovich (No.2) the European Court was forced to concede that, under the directive, a company such as Francovich's could be excluded. ${ }^{38}$ The whole basis for concluding, that there should be a remedy in damages, was based on wrong set of assumptions.

Francovich might be legitimately extended to a case such as Dillenkofer and Others v. Germany ${ }^{39}$ concerning the Package Holidays Directive. ${ }^{40}$ Under the Package Holiday Directive, Member States were required to ensure that package tour operators were fully bonded to cover their customers in the event of their bankruptcy. Germany was over 18 months late in transforming the directive into German law. The plaintiffs had all purchased package tours but the holiday operators went bankrupt, either before the start of the holiday or, in one case, after the outward flight but before the return flight. The plaintiffs were aggrieved by the fact that, if the directive had been transformed into German law by the due date, they would have been protected against the insolvency of the holiday

${ }^{37}$ Supra.n.4.

${ }^{38}$ Andrea Francovich v. Italy (Case C-479/93) [1995] E.C.R. I-3843.

${ }^{39}$ Dillenkofer and others v. Germany (Joined Cases 178,179,188,189 \& 190/94) [1996] E.C.R.I-4845, Tesauro Opinion at 4848.

${ }^{40}$ Directive no. 90/314 O.J. 1990 (L.158/59). 


\section{MORE LAW - LESS ORDERLINESS}

operator.

The Advocate General took the view that the directive was intended to protect holiday makers, that it was clear that the holiday maker was to be reimbursed in the event that the operator went bankrupt and the damage was caused by the failure of the State to transform the directive on time. Of course had the directive been transformed on time, holidays would have been more expensive because tour operators would have been bonded. Some operators would not have survived. There would have been a guarantee by the industry itself which would have been paid for by a further levy. The passenger pays a lower price for a holiday which he knows is not guaranteed but nevertheless has the right to be treated, as far as the advantage is concerned, as if the State had passed the necessary legislation even if he is entirely ignorant of the obligation on the State to pass the necessary legislation.

In his Lomas opinion in 1995, the Advocate General, M. Léger, opted enthusiastically for a very wide principle of state liability that aroused such concern in this country, that the rather more modest principle later adopted by the Court itself, appears to have come as something of a relief. ${ }^{41}$

The extension of the principle to incorrect transposition as opposed to non transposition, was discussed most recently in R.v. H.M.Treasury, ex parte British Telecommunications P.L.C. ${ }^{42}$ The United Kingdom had incorrectly implemented the Public Procurement (Excluded Areas) Directive, by itself deciding matters which, under the directive, ought to have been left to the telecom companies. It is a remarkable directive because in terms it appears to place obligations directly on companies rather than requiring States to impose obligations on companies. In the event the United Kingdom itself imposed an obligation on B.T. to seek clearance in certain cases from the sponsoring department whereas it should have required the telephone companies to deal directly with the Commission, when it, the Company, believed it came within the directive. I suppose it is an example of where a directive could simply have been copied out again as a British regulation.

As regards B.T.'s claim to damages the Court considered that the obligation to pay damages arose wherever the loss sustained by an individual stemmed from the application of national legislation implementing a directive which proved to be wrong, so long as this was a grave and manifest breach of the directive. Since the United Kingdom had adopted a plausible interpretation of the directive,

\footnotetext{
${ }^{41}$ Supra.n.7.
}

${ }^{42}$ (Case C-392/93) [1996] E.C.R. I-1631. 


\section{THE DENNING LAW JOURNAL}

albeit wrong, and, since neither the Commission nor the case law of the court would have made the error clear, there was no liability to make good any loss suffered by B.T.

The importance of this decision, however, is that the British Government had merely got part of the detail of the implementation wrong. The directive was not one intended to require States to confer rights on telephone companies, like the Equal Treatment Directives on people, or the Package Tour Directive, but rather to get States to impose on telecom companies new duties. It suggests that the simple failure to transpose a directive in time could give rise to damages if the mistake was grave and manifest. The right, that the court is safeguarding, is the right to uniform treatment.

A State could not avoid liability for the incorrect implementation of a directive by having the legislation passed as an act of parliament. This was settled in Factortame (No.4) ${ }^{43}$ where the plaintiffs, British Companies which operated fishing vessels, the beneficial owners of which were Spanish fishing interests, claimed they had been forced to sell vessels at a loss or shares at a loss after they were removed from the British shipping register since although their right to register had been restored after Factortame (No.l) ${ }^{44}$ and fully after Factortame (No.2) ${ }^{45}$ they had, in the meantime, been forced to sell their vessels at a loss. The significance of the case was that the decision to take away the right of such Spanish ships to be flagged as British ships was contained in regulations adopted under an Act of Parliament which was passed with that very purpose.

In spite of Germany's elegant plea in the parallel case Brasserie du Pêcheur, ${ }^{46}$ that such constitutional liability should only be created by a solemn constitutional act and not by a judgment of a court, the European Court claimed that it had the right to create this remedy because first, in many of the State legal systems courts had created such remedies. Secondly, the Treaty did not say that there was no such remedy. Thirdly, in International law infringement remained infringement by the State even where it was caused by an act of Parliament and fourthly, a remedy in damages would be a useful weapon in the Community's

\section{${ }^{43}$ Supra.n.7.}

${ }^{44}$ R.v. Secretary of State for Transport, ex parte Factortame Ltd.(No. I) (Case C-213/89) [1990] E.C.R. I-2433.

${ }^{45}$ R.v.Secretary of State for Transport, ex parte Factortame Lid.(No.2) (Case C-221/89) [1991] E.C.R. I-3905.

${ }^{46}$ Supra.n.7. 


\section{MORE LAW - LESS ORDERLINESS}

armoury. The argument for this massive change is once more expediency.

On the ingredients of the claim, both the German Court and the High Court asked the European Court of Justice to give some precision. In Germany, it appeared, there was only liability, at least in theory, where the government had deprived an individual or group of a constitutional guarantee. There was no liability for a legislative act which was of general application. In the United Kingdom there was only liability, at least in theory, where the Government had abused its power towards an individual or class with the intention of causing damage, the tort of misfeasance in a public office.

The European Court held that the conditions required for the tort of misfeasance in a public office could not be transposed to a claim in damages for breach of European Community Law because their application would impede the effectiveness of European Community Law. Liability was based on whether there was a grave and manifest breach of European Law. What the Court meant by grave and manifest is significant. The right of free movement clearly applies to people. The Factortame companies had never moved anywhere: they were and always had been English $£ 100$ companies. The Fishing vessels had not migrated either. What the British rules did was to prevent quota hopping. The area of doubt arose from the issue of how the United Kingdom was expected to distribute a fishing quota, which was assigned by the European Community to the United Kingdom. If the Spanish fishing fleet was entitled, by whatever device, to reflag as British vessels, there would clearly be rather a bizarre consequence. The United Kingdom thought that the needs of the fishing policy could take precedence over nationality rules, which it believed in any event remained in State jurisdiction. Even if it should have realized that it was infringing the right of establishment, if that is what it was, it could reasonably have considered that the assignment of a quota to a State was, by its nature, discriminatory. If this was wrong, it was a mistake made by all other sea fishing states. Neither Spain nor France, for that matter, had allowed foreigners to reflag as French or Spanish ships and, indeed, in both of those countries there were still rules as to the nationality of crews! If a Spanish trawler had sought to be reflagged as a French ship it would not have got over the threshold of liability. Liability for loss has always been a difficult concept in both the civil law and in the common law: whether it should extend to lucrum cessans (expectation loss), or be confined to damnum emergens (reliance loss). Damages, in the context of a failure to transpose a directive, might, at one extreme, represent the sum of money that would put the plaintiff, as nearly as possible, into the position he would have been in, if the State had carried out its obligation, in other words an 


\section{THE DENNING LAW JOURNAL}

expectation liability: the Court seemed to imply in Francovich ${ }^{47}$ that that was the true measure of damage in the Community. That would presumably be the measure in Dillenkofer. ${ }^{48}$ In the Marshall case, the damages which Mrs. Marshall had suffered by being dismissed, in breach of her right to equality, was loss of income. ${ }^{49}$

On the other hand in cases such as Factortame (No.3) ${ }^{50}$ and British Telecom ${ }^{51}$ it seems that reliance loss would be appropriate. According to the Court reparation had to be commensurate with the loss sustained. A State court could also invoke rules on mitigation of damage but damages could not totally exclude loss of profit. This rather Delphic pronouncement is explained by saying that the Court is merely laying down the minimum requirements for State remedies (tacit subsidiarity).

The Court moves from a highly abstract level of principle to concrete determinations but as so often leaves out the crucial reasoning in the middle. At the level that we would look for the rule which is usable in subsequent cases, there is often nothing at all other than hints as to how the principle should be applied.

For all these reasons the trawler companies tried to base their claim, not only on reliance loss and a very novel claim to exemplary or punitive damages based on the claim that the United Kingdom's conduct had been abusive and unconstitutional. The Advocate General seemed to think that such a claim might be a useful addition to the armoury and the European Court said there was nothing against this being used. ${ }^{52}$ The details of the claim were therefore thrown back to the national court to determine where it will, no doubt, be the subject of negotiation.

In the famous Marshall case, where a regional Health Authority was held liable to an employee, I think that the Court took care not to give a ruling on the

${ }^{47}$ Supra.n.4.

${ }^{48}$ Supra.n.39.

${ }^{49}$ Marshall v. Southampton Area Health Authority (No.2) (Case C-271/91) [1993] E.C.R. I-4367.

${ }^{\text {so }}$ Supra.n.7.

${ }^{51}$ Supra.n.42

${ }^{52}$ This is consistent with the normal approach of the Court of approving any means that would ensure the ends of the Treaty efficiently. 
nature of the claim to damages but on the legality of a statutory limit to a claim..$^{53}$ The decision that a statutory limit to a claim is incompatible with the obligations of an emanation of the State seems to me to be the same thing as giving rise to a European claim to damages. It suggests that a local authority that failed to comply with the terms of a directive could be liable in damages.

The State's power to implement Community directives does not derive from the treaties. From the Union comes only the duty to pass binding legislation in implementation of a European directive. This must include the power to get it wrong for which it may be properly liable to the other Member States and, if necessary, to judicial review for breach of the duty to pass binding legislation. By making it liable to its own subjects it changes the nature of the relationship to one of local government. However, even a local government should be liable to subjects only in very narrow circumstances.

The Commission recently gave the results of a report which it had commissioned. It announced with pleasure that many companies in England were blaming the European Union for much regulation which was of United Kingdom origin. This is precisely the confirmation that we needed of the dangers of the process, of the lack of any transparency of who is the master and who the servant. In every federation this is the central issue.

The traditional values of federalism have been much discussed. The values of federalism, in the first place, are said to result from the benefits of competition between States to produce the best and most appropriate legislative structure. In the second place by splitting the range of powers between the general government and the state government there is said to be a greater defence against tyranny than would tend to be possible when a government was perforce remote from the governed. Decision makers would be answerable to the people that they governed and therefore would be to some extent sensitive to public opinion. Decision makers and enforcers would be sufficiently near to understand each others' problems.

In the United States the values of federalism, as opposed to centralism, and therefore of state rights, as opposed to central government powers, are still a significant force, despite the enormous growth in Congressional activity since the war. In 1992, in New York v. United States the Supreme Court had to deal with federal legislation that in many respects resembled what we call a directive. ${ }^{54}$ The issue concerned in part the legal consequences of non-

\footnotetext{
${ }^{53}$ Supra.n.49.

${ }^{54} 505$ U.S. 144 (1992).
} 


\section{THE DENNING LAW JOURNAL}

compliance with the main obligation under an Act of Congress which was intended to work in a similar way to a directive.

Three of the states in the United States had sites for the disposal of radioactive waste. There was political resentment that no efforts were being made to find sites in the other States given that they could not charge higher fees nor restrict imports of waste from other States, without federal approval, since they would thereby be burdening interstate commerce.

A compromise was reached under the auspices of the National Governors Association. By the end of a seven year period, a state could refuse to accept nuclear waste from another state. In the meantime the three states were authorized to impose a progressively rising tax on the import of waste from other states until, at the expiry of the period, it could refuse to accept the waste altogether. The Federal Act which was adopted to give effect to the compromise provided that the tax was in part to go to the recipient state but also into an equalization fund to help states construct disposal sites. At the expiry of the transitional period the Act contained a draconian measure to ensure that the states had complied: if they had not made appropriate arrangements, Congress provided that title to all nuclear waste would automatically vest in the defaulting state. The state would be liable for all disposal costs and for any other liability!

This was a powerful incentive indeed to ensure compliance with the federal legislation. The Supreme Court of the United States quashed the Act on the ground that it sought to direct the state legislative process; not to treat the state government as a sovereign, independent body, but rather as a simple implement of Federal legislation. In U.S. 19th. century language it commandeered the States.

The U.S. model of a federation is one among many and in Europe most think of the German model of a federation as the more appropriate prototype, but there has been no debate. In the German system the federal element most clearly emerges in the decision making process but for the rest is centralized. The principle of the German Constitution, like that of the European Union, is subsidiarity. Legislation should be passed where it is most appropriate or efficient as opposed to the, at least on paper, functional division of the United States Constitution. Even in such traditional state matters as education and the regulation of professions there is federal legislation in Germany.

If nothing fundamental is done, at the level of principle rather than at the level of practice the Court will itself continue the process of constitutionalisation: the Court has what one of the Advocate Generals described as une certaine idée de 


\section{MORE LAW - LESS ORDERLINESS}

l'europe. ${ }^{55}$ The lawyer has to share the image of a single market and of the relationship of common policies to that market propounded from time to time by the Court. It encompasses very wide principles of interpretation, the principle of effectiveness above all, the importance of uniform application, the necessity for a State court to deduce rights from European Community obligations imposed on States, principles which are hardly adequate or even desirable principles for a federation. That this vision is so at variance with both the vision and the customary thought processes of the élites in this country, is the primary reason why a relatively law-abiding country finds itself caricatured as a reactionary, insular and nationalistic one by some of those who appear to us to be riding roughshod over the rules of the Treaty. This is because in the process of constitutionalisation, European Law is only really significant at the level of principle and vision rather than at the level of practical application. This is why a Member State can have a far worse record of compliance and yet be seen as a better European.

The contribution that the court has made towards greater integration should not be trivialized. On the other hand its rapid developments of the law may have delayed a more rational, more acceptable federation which would have more readily presented a united voice to the outside world in which I have always believed. If all this was building a true sense of European identity then I suppose it might be tolerable. I see no evidence that that is so. Pressure groups, consumer, environmental, trades union have been the net beneficiaries of the new centralism since it has given them a power that transcends the State but it is not likely to win over the hearts of the electorate.

The Court's single minded and impressive transformation of the directive from interstate instrument, compliance with which could be assured in the European Court, into a source of paramount rules which could be litigated in State courts, may well have slowed down the European Union construction and in particular isolated an important sector of opinion in this country. It may have contributed to the popular opposition in the United Kingdom to the adoption of many important small measures on which, in the longer term, our sense of shared identity would have been based.

Before the Intergovernmental Conference the U.K. government flew a kite to see if there would be any support for a plan to kerb the powers of the Court of Justice of the European Communities. ${ }^{56}$ There was no support.

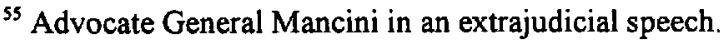

${ }^{56}$ As the French President Giscard d'Estaing had done a decade earlier.
} 


\section{THE DENNING LAW JOURNAL}

The only way that could break out of this gridlock is to push for a more open, more plausible and, more federal, method of legislating if we are not to do even more damage to the rule of law. This was one of the other subjects on the agenda of the Intergovernmental Conference leading to the Maastricht Treaty, but is now adjourned sine die. The certain idea of Europe has to be made more public and must receive proper consent. Without a new constitutional settlement, a Member State may well be blamed for something that is the work of the centre and the centre blamed for something that is the work of the State. That way leads to bewilderment, lack of accountability and more importantly the replacement of the rule of law with the rule of policy.

That is no recipe for a stable future. The United Kingdom needs to take the initiative. The debate on the Constitution of the European Union needs to be opened up. If not the Member States will find themselves sucked ever more closely into a loveless centralized organization. In that organization, the United Kingdom will be pitied, patronized and no doubt will play out that assigned role with conviction. The only way the United Kingdom can change that dreadful destiny is either by getting out and thereby losing everything or by taking the lead in transforming the Union into a properly constituted federation with an acceptable division of functions not dependent on a political doctrine of subsidiarity itself originally propounded by the most centralised organization in the world. ${ }^{57}$

${ }^{57}$ The Vatican. The doctrine of subsidiarity originated in the pontifical encyclical Quadragessima Anno. 